\title{
MANAJEMEN KURIKULUM DALAM MENINGKATKAN MUTU LULUSAN MADRASAH IBTIDAIYAH
}

\author{
Nunik Pramulyani, Achmad Ali Fikri \\ Institut Agama Islam Negeri Kudus \\ nunikpramulyani@gmail.com
}

\begin{abstract}
Education is an important thing that supports the progress of a country. Because with quality education will produce quality individuals, who are able to compete with other countries and be able to face the flow of globalization. Then we need to support and participate in advancing education. The quality of education will be satisfactory if managed well. To achieve good education there is a need for good management, especially in the curriculum. Curriculum management is a regulatory activity that includes planning, organizing, implementing, and evaluating so that the education program can run well and in accordance with the expected goals. By implementing good curriculum management, these educational institutions will produce quality graduates.
\end{abstract}

Keywords: Curriculum Management, Graduate Quality

\begin{abstract}
ABSTRAK
Pendidikan merupakan hal penting yang mendukung kemajuan suatu Negara. Karena dengan pendidikan yang berkualitas akan menghasilkan individu-individu yang berkualitas, yang mampu bersaing dengan negara-negara lain dan mampu menghadapi arus globalisasi. Maka kita perlu mendukung dan ikut serta dalam memajukan pendidikan. Mutu pendidikan akan memuaskan apabila dikelola dengan baik. Untuk mencapai pendidikan yang baik diperlukan adanya manajemen yang baik terutama dalam bidang kurikulum. Manajemen kurikulum adalah kegiatan pengaturan yang meliputi perencanaan, pengorganisasian, pelaksanaan, dan evaluasi agar program pendidikan dapat berjalan dengan baik dan sesuai dengan tujuan yang diharapkan. Dengan menerapkan manajemen kurikulum yang baik, lembaga pendidikan tersebut akan menghasilkan lulusan yang bermutu.
\end{abstract}

Kata kunci: Manajemen kurikulum, Mutu lulusan.

\section{PENDAHULUAN}

Dalam kehidupan manusia tidak lepas dengan aktivitas pendidikan. Pendidikan merupakan usaha yang dilakukan pendidik terhadap peserta didik agar tercapai perkembangan maksimal yang positif. (Ahmad Tafsir, 2014: 38). Pendidikan merupakan salah satu usaha untuk membentuk generasi yang berkualitas. Pendidikan menjadi faktor penting yang mendukung kemajuan suatu bangsa. Pendidikan yang maju akan menghasilkan sumber daya manusia yang berkualitas, yang mampu bersaing dengan negara-negara lain dan mampu menghadapi masalah-masalah yang dihadapi dimasa yang akan datang. Namun sebaliknya jika pendidikan suatu negara mengalami kemunduran, maka akan terbelakang dalam segala bidang.

Untuk menciptakan pendidikan yang berkualitas diperlukan peran lembaga pendidikan yang mampu mengelola potensi secara maksimal, baik dari pendidik, 
peserta didik, proses pembelajaran, sarana prasarana, pembiayaan maupun hubungan dengan masyarakat sekitar. Jadi lembaga pendidikan harus mampu memahami situasi dan kondisi lingkungan sekitar, untuk menggali potensi yang dimiliki. Maka perlu adanya kegiatan manajemen. Manajemen menjadi sangat penting untuk menciptakan pendidikan yang berkualitas, terutama manajemen kurikulum. Manajemen kurikulum meliputi perencanaan, pengorganisasian, pelaksanaan dan evaluasi dilakukan supaya program pendidikan berjalan lancar, terarah dan dapat mencapai tujuan pendidikan yang diharapkan.

Mutu lulusan menjadi tolak ukur atau acuan penilaian keberhasilan pendidikan sekolah. Karena pendidikan yang berhasil dan berkualitas akan menghasilkan lulusanlulusan yang bermutu dan berdaya saing. Namun mutu lulusan tidak terjadi begitu saja, tetapi perlu adanya usaha yang sistematis untuk meningkatkan mutu lulusan. Salah satu usaha yang perlu dilakukan dengan sebaik mungkin yaitu manajemen kurikulum. Manajemen kurikulum Madrasah Ibtidaiyah perlu dilakukan, supaya menghasilkan lulusan MI yang mampu bersaing untuk melanjutkan ke jenjang pendidikan selanjutnya yaitu sekolah menengah pertama.

\section{Pengertian Manajemen Kurikulum}

Sumber Manajemen adalah suatu proses nyata tentang perencanaan, pengorganisasian, penggerakan, pengendalian yang dilakukan untuk menentukan dan mencapai tujuan yang telah ditetapkan melalui pemanfaatan sumber daya manusia dan sumber daya lainnya (Zainal Arifin, 2014: 25). Manajemen adalah perumusan sekelompok orang untuk menggunakan segenap kekuatan atau usaha yang maksimal dalam rangka mencapai tujuan yang diinginkan (Abdul Manab, 2016:2). Dalam kegiatan manajemen setiap orang mengerahkan seluruh kemampuannya dengan berbagai tindakan dan alat yanga ada untuk mencapai hasil yang diinginkan. Untuk mencapai keberhasbagi ilan manajemen diperlukan adanya tanggung jawab dan kerjasama yang baik antar individu.

Kurikulum adalah suatu program pendidikan yang berisikan berbagai bahan ajar dan pengalaman belajar yang diprogramkan dan direncanakan secara sistemik atas dasar norma-norma yang berlaku yang dijadikan pedoman dalam proses pembelajaran bagi tenaga kependidikan dan peserta didik untuk mencapai tujuan pendidikan (Abdul Manab, 2016: 118). Kurikulum dalam konsep lama berarti mata pelajaran yang harus dipelajari untuk memperoleh ijazah. Dan kurikulum dalam konsep modern berarti pengalaman yang mempengaruhi kualitas pendidikan baik secara langsung maupun tidak langsung. Jadi kurikulum secara singkat dapat dimaknai sebagai pengalaman, peristiwa yang berpengaruh. Kurikulum memiliki ruang lingkup yang luas. Maka untuk memudahkan dalam memahami kurikulum, maka kurikulum dibagi menjadi tiga yaitu ( M Saekan Muchith, 2011:29):

1. Kurikulum potensial

Kurikulum potensial yaitu sejumlah dokumen tertulis, gambar atau rekaman yang dijadikan landasan atau dasar atau pijakan sekolah atau guru dalam melaksanakan penyelenggaraan pendidikan atau pembelajaran atau dengan kata lain seluruh dokumen untuk memajukan mutu pendidikan. Misalnya visi misi sekolah, program atau perencanaan dalam bidang pembelajaran, silabus, RPP, administrasi pembelajaran. 
2. Kurikulum Faktual

Kurikulum faktual yaitu realitas proses pembelajaran yang dilakukan oleh guru atau hal-hal yang terjadi dalam proses pembelajaran.

3. Kurikulum tersembunyi

Kurikulum tersembunyi yaitu sesuatu atau perilaku guru dan peserta didik yang tidak direncanakan atau tidak disetujui tetapi memiliki pengaruh secara langsung maupun tidak langsung dalam proses pembelajaran.

Manajemen kurikulum adalah seluruh usaha untuk memperlancar pencapaian tujuan pembelajaran yang menekankan pada usaha untuk meningkatkan kualitas pembelajaran. Manajemen Kurikulum memiliki makna pengorganisasian kurikulum yaitu menyusun atau melaksanakan kurikulum melalui pembelajaran (guru). Manajemen kurikulum dan pembelajaran mempunyai bidang cakupan (Abdul Manab, 2016:118-119):

1. Penyusunan/ review kurikulum dan silabus.

2. Penyusunan kalender pendidikan.

3. Penyusunan program tahunan.

4. Penyusunan rencana pelaksanaan pembelajaran (RPP).

5. Pembagian tugas mengajar dan tugas lain.

6. Penyusunan jadwal pelajaran.

7. Penyusunan jadwal kegiatan perbaikan.

8. Penyusunan jadwal kegiatan ekstrakulikuler.

9. Penyusunan program jadwal kegiatan bimbinagan dan penyuluhan.

10.Pengaturan pembukaan tahun ajaran.

11.Pelaksanaan kegiatan pembelajaran

12.Pelaksanaankegiatan bimbingan dan penyuluhan.

13.Supervisi pelaksanaan pembelajaran.

14. Supervisi pelaksanaan bimbingan dan penyuluhan.

Kurikulum berusaha melestarikan nilai-nilai budaya, namun disisi yang lain kurikulum berusaha mengikuti perubahan zaman, karena kurikulum bertujuan menyiapkan peserta didik untuk menjalani kehidupan dimasa depan.

\section{Prinsip Manajemen Kurikulum}

Dalam melaksanakan manajemen kurikulum, ada lima prinsip yang harus menjadi perhatian penting yaitu (M Arif Khoirudin, 2013: 60) :

1. Produktivitas

Hasil yang akan diperoleh dalam kegiatan kurikulum merupakan aspek yang harus dipertimbangkan dalam manajemen kurikulum. Pertimbangan bagaimana agar peserta didik dapat mencapai hasil belajar sesuai dengan tujuan kurikulum harus menjadi sasaran dalam manajemen kurikulum.

2. Demokratisasi

Pelaksanaan manajemen kurikulum harus berasaskan demokrasi yang menempatkan pengelola, pelaksana dan subjek didik pada posisi yang seharusnya dalam melaksanakan tugas dengan tanggung jawab untuk mencapai tujuan kurikulum.

3. Kooperatif

Madrosatuna: Jurnal Pendidikan Guru Madrasah Ibtidaiyah 2(1) (2019) 1-10 
Untuk memperoleh hasil yang diharapkan dalam kegiatan manajemen kurikulum perlu adanya kerjasama yang positif dari berbagai pihak yang terlibat.

4. Efektivitas dan efisiensi

Rangkaian kegiatan manajemen kurikulum harus mempertimbangkan efektivitas dan efisiensi untuk mencapai tujuan kurikulum sehingga kegiatan manajemen kurikulum tersebut memberikan hasil yang berguna dengan biaya, tenaga, dan waktu yang relatif singkat.

5. Mengarahkan visi, misi, dan tujuan yang ditetapkan dalam kurikulum

Proses manajemen kurikulum harus dapat memperkuat dan mengarahkan visi, misi, dan tujuan kurikulum.

\section{Fungsi Manajemen Kurikulum}

Perlu adanya manajemen kurikulum dalam proses pendidikan untuk memberikan hasil kurikulum yang lebih efektif, efisien dan optimal dalam memberdayakan berbagai sumber maupun komponen kurikulum. Sehingga manajemen kurikulum memiliki berbagai fungsi antara lain adalah sebagai berikut( M Arif Khoirudin, 2013: 61-62):

1. Meningkatkan efisiensi pemanfaatan sumber daya kurikulum

Pemberdayaan sumber maupun komponen kurikulum dapat ditingkatkan melalui pengelolaan yang terencana dan efektif.

2. Meningkatkan keadilan dan kesempatan pada siswa untuk mencapai hasil yang maksimal

Kemampuan yang maksimal dapat dicapai peserta didik tidak hanya melalui kegiatan intrakulikuler, tetapi juga perlu melalui kegiatan ekstra yang dikelola secara integritas dalam mencapai tujuan kurikulum.

3. Meningkatkan relevansi dan efektivitas pembelajaran sesuai kebutuhan peserta didik Kurikulum yang dikelola secara eektif dapat memberikan kesempatan dan hasil yang relevan dengan kebutuhan peserta didik maupun lingkungan sekitar.

4. Meningkatkan efektivitas kinerja pendidik maupun aktivitas peserta didik dalam mencapai tujuan pembelajaran

Dengan penegelolaan kurikulum yang profesional, efektif dan terpadu dapat memberikan motivasi pada kinerja pendidik maupun aktivitas peserta didik dalam belajar.

5. Meningkatkan efisiensi dan efektivitas proses belajar mengajar

Proses pembelajaran selalu dipantau dalam rangka melihat konsistensi antara desain yang telah direncanakan dengan pelaksanaan pembelajaran. Dengan demikian ketidaksesuaian anatara desain dan implementasi dapat dihindarkan. Pendidik dan peserta didik selalu termotivasi untuk melaksanakan pembelajaran yang efektif dan efisien, karena adanya dukungan kondisi positif yang diciptakan dalam kegiatan pengelolaan kurikulum.

6. Meningkatkan partisipasi masyarakat untuk membantu mengembangkan kurikulum Kurikulum yang dikelola secara profesional kan melibatkan masyarakat khususnya dalam mengisi bahan ajar atau sumber belajar perlu disesuaikan dengan ciri khas dan kebutuhan pembangunan daerah setempat.

\section{Implementasi Manajemen Kurikulum}

Madrosatuna: Jurnal Pendidikan Guru Madrasah Ibtidaiyah 2(1) (2019) 1-10 
Langkah-langkah dan implementasi kurikulum perlu dirumuskan oleh madrasah melalui manajemen yang meliputi: perencanaan, pengorganisasian, implementasi dan evaluasi (M Arif Khoirudin, 2013:62).

1. Perencanaan kurikulum

Perencanaan merupakan suatu kegiatan menentukan langkah dan alat yang dibutuhkan untuk mencapai hasil yang diinginkan dengan seefektif mungkin. Perencanaan kurikulum adalah perencanaan strategi atau langkah-langkah yang digunakan untuk mencapai tujuan pendidikan, tujuan disini dimaksudkan perubahan tingkah laku peserta didik untuk menyiapkan peserta didik menjadi generasi yang mampu menghadapi masalah-masalah yang akan dihadapi di masa yang akan datang. Dalam perencanaan kurikulum erat kaitannya dengan materi pelajaran, jadi seorang pendidik perlu menyiapkan materi dan merencanakan kegiatan pembelajaran secara sistematis supaya tujuan pembelajaran dapat tercapai secara maksimal yakni peserta didik mampu memahami dan mengaplikasikan materi yang telah disampaikan guru.

Dalam perencanaan kurikulum terdapat beberapa langkah yang harus dilaksanakan antara lain (M Arif Khoirudin, 2013: 64-65):

a. Berdasarkan kalender pendidikan dari Kementrian Pendidikan, sekolah menghitung hari kerja efektif untuk setiap mata pelajaran, menghitung hari libur, hari untuk ulangan dan hari kerja tidak efektif.

b. Menyusun program tahunan (Prota)

Program tahunan merupakan program untuk setiap mata pelajaran untuk setiap kelas, yang dikembangkan oleh guru mata pelajaran yang bersangkutan. Prota perlu disiapkan sebelum tahun ajaran karena merupakan pedoman untuk pengembangan program-program berikutnya, yaitu program semester, program mingguan dan program harian.

c. Menyusun program semester (Promes)

Dalam program semester dijelaskan beberapa jumlah standar kompetensi dan kompetensi dasar, bagaimana cara menyelesaikannya, kapan diajarkan melalui tatap muka tau tugas.

d. Menyusun silabus

Dalam kegiatan ini guru menyusun rencana secara rinci mencakup standar kompetensi, kompetensi dasar, indikator, pengalaman belajar dan sistem penilaian yang dilakukan untuk mengetahui pencapaian tujuan pengajaran.

e. Menjabarkan silabus menjadi rencana pembelajaran

Kegiatan dalam tahap ini adalah mengkaji standar kompetensi dan kompetensi dasar yang esensial yang sulit dipahami oleh peserta didik dijadikan prioritas untuk dipelajari dalam tatap muka dan yang tidak begitu sulit dijadikan tugas individu atau kelompok.

f. Rencana Pembelajaran

Kegiatan dalam tahap ini adalah guru membuat rincian pelajaran untuk satu kali tatap muka. Yang penting dalam rencana pembelajaran adalah harus ada catatan kemajuan siswa setelah mengikuti pelajaran, untuk evaluasi rencana pembelajaran berikutnya. 
Untuk merencanakan kurikulum kepala sekolah perlu membimbing dan membantu guru yang kesulitan. Dan untuk mempermudah dapat dilakukan secara bersama melalui musyawarah guru mata pelajaran (MGMP).

2. Pengorganisasian

Organisasi adalah suatu sistem, mempunyai struktur dan perencanaan yang dilakukan dengan penuh kesadaran, didalamnya orang-orang bekerja dan berhubungan satu sama lain dengan suatu cara yang terkoordinasi dan kooperatif guna menapai tujuan-tujuan yang ditetapkan (M Arif Khoirudin, 2013: 67). Pengorganisasian merupakan langkah awal menuju pelaksanaan, yang menghasilakan suatu organisasi untuk mencapai tujuan dan rencana yang telah ditentukan. Keberhasilan manajemen dalam melaksanakan fungsi pengorganisasian dapat dinilai dari kemampuannya untuk menciptakan organisasi yang baik. Organisasi berfungsi untuk (M Arif Khoirudin, 2013: 68):

a. Mengatur tugas dan kegiatan kerjasama sebaik-baiknya.

b. Mencegah kelambatan-kelambatan kerja serta kesulitan yang dihadapi.

c. Mencegah kesimpangsiuran kerja.

d. Menentukanpedoman-pedoman kerja.

Dengan adanya organisasi akan memberikan keuntungan anata lain (M Arif Khoirudin, 2013: 68):

a. Setiap individu akan mengetahui tugasnya masing-masing.

b. Memperjelas hubungan kerja para anggota organisasi.

c. Terdapat koordinasi yang tepat antar unit kerja.

d. Menggunakan tenaga kerja sesuai dengan kemampuan dan minat.

e. Kegiatan administrasi serta manajemen dapat dilakukan secara efektif dan efisien.

Pada tahap pengorganisasian wakil kepala bagian kurikulum bertugas ( M Arif khoirudin, 2013: 70):

a. Membagi tugas mengajar secara merata sesuai keahlian dan minat guru. Hal ini akan membuat pelaksana atau pekerja akan senang, antusias dan menikmati pekerjaannya karena sesuai dengan minat dan keahliannya sehingga kesulitan yang dihadapi sedikit.

b. Menyusun jadwal pelajaran,diupayakan pendidik mengajar 5 hari kerja sehingga ada waktu untuk istirahat ataumengerjakan tugas lain.

c. Menyusun jadwal perbaikan dan pengayaan peserta didik, sehingga peserta didik yang belum memenuhi KKM mendapat kesempatan memperbaiki.

d. Menyusun jadwal ekstra kulikuler sehingga peserta didik ada kesempatan untuk mengasah atau meningkatkan keterampilan dan bakatnya.

e. Menyusun jadwal penyegaran guru, diamksudkan supaya guru memiliki tambahan pengetahuan dalam mengajar baik dalam penggunaan strategi, media ataupun materi pelajaran.

3. Pelaksanaan

Implementasi kurikulum merupan penerapan atau pelaksanaan program kurikulum yang telah dikembangkan dalam tahap sebelumnya, kemudian diuji cobakan dengan pelaksanaan dan pengelolaan, sambil dilakukan penyesuaian 
terhadap situasi lapangan dan karakteristik peserta didik, baik perkembangan intelektualnya, emosional, serta fisiknya (M Arif khoirudin, 2013: 70). Dalam pelaksanaan kurikulum kepala sekolah bertugas melakukan supervisi untuk membantu guru mengatasi kesulitan yang dihadapi. Beberapa hal yang menjadi tugas kepala sekolah dalam pelaksanaan kurikulum antara lain (M Arif Khoirudin, 2013, 72):

a. Membimbing guru untuk memilih bahan pelajaran, sehingga bahan pelajaran yang diajarkan sesuai dengan tingkatan peserta didik dan sesuai dengan kebutuhan dalam masyarakat.

b. Membimbing guru dalam memilih metode mengajar, metode yang digunakan hendaknya sesuai dengan tingkat kecerdasan peserta didik sehingga peserta didik mampu menerima dan memahami materi yang disampaikanguru.

c. Menyelenggarakan rapat dewan guru, rapat dimaksudkan untuk menerima pendapat atau usulan para guru untuk perbaikan kegiatan pembelajaran ataupun program sekolah.

d. Mengadakan kunjungan kelas secara teratur, supaya mengetahui metode dan strategi yang digunakan guru untuk mengajar sebagai bahan evaluasi.

e. Pendidik diwajibkan menyusun prota, promes, silabus, rencana pembelajaran.

f. Pada akhir tahun ajaran melakukan evaluasi, dan selanjutnya melakukan perbaikan pada tahun ajaran berikutnya.

g. Melakukan penelitian tentang situasi dan kondisi sekolah sebagai pedoman dalam membuat program sekolah.

Pelaksanaan kurikulum ditekankan pada usaha-usaha yang harus dilakukan untuk meningkatkan kualitas pembelajaran. Dengan harapan kurikulum dapat terlaksana dengan maksimal sehingga mampu menghasilkan lulusan yang bermutu.

\section{Evaluasi}

Evaluasi kurikulum adalah suatu proses yang sistematis dari pengumpulan, analisis dan interpretasi informasi/data untuk menentukan sejauh mana peserta didik telah mencapai tujuan pembelajaran. (M Arif Khoirudin, 2013: 72-73). Evaluasi kurikulum memiliki peranan penting untuk menentukan kebijakan atau keputusan. Karena dengan adanya evaluasi maka hasil evaluasi dijadikan acuan atau cermin untuk mengambil keputusan. Pendidik sebagai manajer pembelajaran jika ada suatu yang jauh atau tidak sesuai dengan yang telah direncanakan maka perlu mengambil langkah yang tepat untuk mencapai tujuan yang telah direncanakan. Jadi evaluasi sangat penting demi perbaikan-perbaikan selanjutnya.

\section{Pengertian Mutu}

Mutu adalah faktor keputusan mendasar dari pelanggan (Abdul Manab,2016: 143). Keputusan tersebut berdasarkan pengalaman pelanggan dalam menggunakan produk atau pelayanan jasa. Menurut Feigenbaum, mutu produk dan jasa adalah seluruh gabungan sifat-sifat produk atau jasa pelayanan dari pemasaran, engineering, manufaktur, dan pemeliharaan dimana produk atau jasa pelayanan dalam penggunaannya akan bertemu dengan pelanggan. Dan menurut Goets dan Davis, kualitas merupakan suatu kondisi dinamis yang berhubungan dengan produk, jasa, 
manusia, proses, dan lingkungan yang memenuhi atau melebihi harapan. Menurut Douglas, konsep mutu mencakup tiga hal yaitu: mencakup semua proses, mencakup setiap pekerjaan, yangmencakup setiap orang, yang disebut dengan istilah mutu terpadu.Dan menurut J.M. Juran, mutu adalah kecocokan dalam penggunaan. Lebih lanjut iamengungkapkan bahwa banyak arti tentang mutu namun ada dua hal yang penting bagi manajer meskipun tidak semua pelanggan menyadarinya yaitu: mutu sebagai keistimewaan produk ( semakin banyak keistimewaan produk semakin tinggi mutunya) dan mutu berarti bebas kekuranagan (semakin sedikit kekurangan semakin baik mutunya) (Abdul Manab,2016: 144-146). Dari beberapa definisi para ahli diatas dapat disimpulkan bahwa mutu adalah suatu keunggulann atau keistimewaan dari suatu produk atau jasa. Mutu tidak hanya dilihat atau dinilai dari hasilnya saja namun dinilai dari segi prosenya, tingkat kepuasan pelanggan, ketepatan dalam memenuhi standar yang telah ditentukan.

Dalam menciptakan produk dan jasa pelayanan harus memberikan keunggulan ataui keistimewaan dibandingkan kompetitor. Hal ini dimaksudkan agar mampu bersaing menarik pelanggan. Karena produk dan jasa yang bermutu atau berkualitas akan dicari pelanggan. Peningkatan mutu pendidikan menjadi tugas utama kepala sekolah dan para pendidik untuk menjadikan lembaga tempat ia bekerja menjadi sekolah unggulan. Peningkatanmutu dimaksudkan untuk menarik lebih banyak peserta didik

Mutu dalam konteks pendidikan merupakan usaha para akademisi pendidikan dalam mewujudkan peserta didik yang mampu menghadapi tantangan dan tetap bertahan dalam kehidupannya dimasa yang akan datang. Mutu pendidikan meliputi(Abdul Manab, 2016:153):

a. Siswa yang sehat, cukup gizi, siap untuk belajar bersama, serta didukung oleh keluarga dan masyarakat disekitarnya.

b. Lingkungan yang kondusif, aman, serta dilengkapi dengan sumber belajar dan fasilitas yang memadai.

c. Materi belajar yang tercermin dalam kurikulum yang baik dan relevan.

d. Proses belajar yang menempatkan siswa sebagai pusat belajar di dalam kelas yang terorganisasi dengan baik.

e. Lulusan yang menguasai pengetahuan, ketrampilan, dan perilaku yang sesuai dengan tujuan pendidikan nasional, serta mampu berpartisipasi dalam kehidupan masyarakat.

Peran Kurikulum dalam Mewujudkan Mutu Lulusan Madrasah Ibtidaiyah

Penyelenggaraan pendidikan madrasah ibtidaiyah bertujuan menciptakan lulusan yang berkarakter, cakap, terampil dan berwawasan luas sehingga mampu menghadapi mampu bersaing pada tingkat pendidikan selanjutnya dan mampu menghadapi serta menyesuaikan perkembangan zaman. Lulusan madrasah ibtidaiyah diharapkan memiliki kompetensi sebagai berikut (Ramayulis, 2005:44):

1. Mengenali dan berperilaku sesuai ajaran agama yang diyakini.

2. Mengenali dan menjalankan hak dan kewajiban diri, beretos kerja, dan peduli terhadap lingkungan.

3. Berpikir secara logis, kritis, dan kreatif serta berkomunikasi melalui berbagai media.

4. Menyenangi keindahan.

Madrosatuna: Jurnal Pendidikan Guru Madrasah Ibtidaiyah 2(1) (2019) 1-10 
5. Membiasakan hidup bersih, bugar dan sehat.

6. Memiliki rasa cinta dan bangga terhadap bangsa dan tanah air.

Paradigma yang harus dipenuhi dalammeningkatkan mutu pendidikan madrasah sebagai berikut (Nurhasnawati, 2015: 92-96):

1. Mempertegas visi, misi, orientasi, tujuan, dan strategi mencapai cita-cita pendidikan Fasilitas, sarana prasarana, dan perangkat pembelajaran seperti kurikulum, prota, promes, silabus, RPP, media pembelajaran sangat menunjang terlaksananya visi dan misi madrasah, untuk menghasilkan lulusan yang bermutu.

2. Demokrasi pendidikan madrasah

Dalam proses pendidikan madrasah harus menekankan peran peserta didik secara aktif, sehingga tercipta peserta didik yang tumbuh menjadi individu yang aktif, kreatif, kritis dan produktif.

3. Paradigma otonomi

Madrasah memiliki kesempatan untuk mandiri mengatur administrasi dalam bingkai kemasyarakatan. Madrasah sebaiknya berlapang dada menerima kritik dan saran dari masyarakat supaya menjadi lembaga yang mampu mendampingi masyarakat menghadapi kebutuhan seiring perubahan zaman.

4. Akuntabilitas

Untuk meningkatkan mutu pendidikan perlu adanya pelatiahan guru supaya mamapu menjadi fasilitator yang baik bagi peserta didik, melakukan manajemen pendidikan, manajemen pengembangan kurikulum.

5. Profesionalisme

Dalam peningkatan mutu pendidikan diperlukan peran tenaga kependidikan yang profesional, dalam hal ini kepala sekolah dan guru. Guru sebagai pendidik memiliki peran yang utama karena sebagai penanggung jawab yang langsung berinteraksi dengan peserta didik dalam proses pembelajaran.

6. Pendanaan Madrasah

Dalam hal pendanaan pendidikan indonesia belum sepenuhnya tercukupi atau memadai. Perlu upaya yang terprogram untuk mendapatkan anggaran pendidikan yang memadai demi terapainya peningkatan kualitas pendidikan.

7. Membangun jaringan (networking)

Upaya peningkatan kualiatas pendidikan tidak cukup dengan dana dan sarana prasarana, perlu adanya kerja sama berbagai pihak yang berorientasi pada mutu pendidikan, baik kerja sama antar madrasah, maupun dengan masyarakat sekitar.

\section{PENUTUP}

Manajemen kurikulum merupakan usaha untuk memperlancar tercapainya tujuan pembelajaran yang menekankan pada usaha dan kualitas mengajar secara efektif dan efisien. Dalam manajemen kurikulum harus memperhatikan perinsip produktivitas, kooperatif, efektif dan efisien, serta mengarahkan visi, misi dan tujuan yang ditetapkan dalam kurikulum. Dan dalam pelaksanaan kurikulum dilakukan melalui tahap perencanaan, pengorganisasian, pelaksanaan dan evaluasi. Manajemen kurikulum dimaksudkan untuk menciptakan lulusan yang berkarakter, cakap, terampil dan berwawasan luas. Langkah yang dapat ditempuh untuk mencapai mutu lulusan dengan 
mempertegas visi misi madrasah, demokrasi pendidikan madrasah, paradigma otonomi, akuntabilitas, profesionalisme, pendanaan dan membangun jaringan. Jadi manajemen kurikulum sangat penting sebagai langkah menghasilkan mutu lulusan madrasah dengan efektif dan efisien.

\section{DAFTAR PUSTAKA}

Arifin, Zainal. (2014). Konsep dan Pengembangan Kurikulum. Bandung: PT Remaja Rosdakarya.

Khoirudin, M Arif. (2013). Manajemen Kurikulum dalam Meningkatkan Mutu Pendiddikan. Cendekia. Vol. 24 No. 01. Januari 2013.

Manab, Abdul. (2016). Manajemen Kurikulum Pembelajaran di Madrasah. Yogyakarta: Kalimedia.

Muchith, M Saekan. (2011). Penegembangan Kurikulum PAI. Kudus: Nora Media Enterprise.

Nurhasnawati. (2015). Pendidikan Madrasah dan Prospeknya dalam Pendidikan Nasional. Potensia. Vol. 14 No. 01. Januari-Juni 2015.

Ramayulis. (2005). Metodologi Pendidikan Agama Islam. Jakarta: Kalam Mulia

Tafsir, Ahmad. (2014). Ilmu Pendidikan Islam. Bandung: PT Remaja Rosdakarya. 